\title{
Purification and Characterization of Glucose-6-Phosphate Dehydrogenase from Camel Liver
}

\author{
Mahmoud A. Ibrahim, ${ }^{1}$ Abdel-Hady M. Ghazy, ${ }^{1}$ Ahmed M. H. Salem, \\ Mohamed A. Ghazy, ${ }^{2}$ and Mohamed M. Abdel-Monsef ${ }^{1}$ \\ ${ }^{1}$ Molecular Biology Department, National Research Center, Dokki, Cairo 12311, Egypt \\ ${ }^{2}$ Biochemistry Department, Faculty of Science, Ain Shams University, Cairo 11566, Egypt \\ Correspondence should be addressed to Mahmoud A. Ibrahim; ibrahimm70@yahoo.co.uk
}

Received 2 October 2014; Accepted 23 November 2014; Published 25 December 2014

Academic Editor: Joaquim Cabral

Copyright (C) 2014 Mahmoud A. Ibrahim et al. This is an open access article distributed under the Creative Commons Attribution License, which permits unrestricted use, distribution, and reproduction in any medium, provided the original work is properly cited.

\begin{abstract}
Glucose-6-phosphate dehydrogenase from camel liver was purified to homogeneity by ammonium sulfate precipitation and a combination of DEAE-cellulose, Sephacryl S-300 gel filtration, and 2', 5' ADP Sepharose 4B affinity chromatography columns. The specific activity of camel liver G6PD is increased to 1.80438 units/mg proteins with 63 -fold purification. It turned out to be homogenous on both native PAGE and 12\% SDS PAGE, with a molecular weight of $64 \mathrm{kDa}$. The molecular weight of the native form of camel liver G6PD was determined to be $194 \mathrm{kDa}$ by gel filtration indicating a trimeric protein. The $K_{m}$ value was found to be $0.081 \mathrm{mM}$ of $\mathrm{NADP}^{+}$. Camel liver G6PD displayed its optimum activity at $\mathrm{pH} 7.8$ with an isoelectric point $(\mathrm{pI})$ of $\mathrm{pH}$ 6.6-6.8. The divalent cations $\mathrm{MgCl}_{2}, \mathrm{MnCl}_{2}$, and $\mathrm{CoCl}_{2}$ act as activators; on the other hand, $\mathrm{CaCl}_{2}$ and $\mathrm{NiCl}_{2}$ act as moderate inhibitors, while $\mathrm{FeCl}_{2}, \mathrm{CuCl}_{2}$, and $\mathrm{ZnCl}_{2}$ are potent inhibitors of camel liver G6PD activity. NADPH inhibited camel liver G6PD competitively with $K_{i}$ value of $0.035 \mathrm{mM}$. One binding site was deduced for NADPH on the enzyme molecule. This study presents a simple and reproducible purification procedure of G6PD from the camel liver.
\end{abstract}

\section{Introduction}

Glucose-6-phosphate dehydrogenase (G6PD, EC 1.1.1.49, $\beta$ D-glucose-6-phosphate; NADP oxidoreductase) is the initial and the key regulatory enzyme in the pentose phosphate pathway [1-4]. It catalyzes the first step of the pentose phosphate pathway (PPP) [5] which is responsible for the production of NADPH and ribose-5-phosphate [6]. G6PD catalyzes the conversion of glucose 6-phosphate to 6phosphogluconate in the presence of NADP [7-10]. Pentose phosphate pathway has three important functions: (i) serving as the route of entry of pentoses to the glycolytic pathway production of reducing equivalents in the form of NADPH; (ii) production of pentose phosphates necessary for nucleotide biosynthesis; and (iii) production of reducing equivalents in the form of NADPH [5, 11-13].

NADPH is a hydrogen and electron donor for many of metabolic reactions [3], including fatty acid and cholesterol biosynthesis. NADPH is essential for protecting the cell against oxidative stress by transferring its reductive power to oxidized glutathione (GSSG) via glutathione disulfide reductase (GR) [14]. NADPH is also required for maintenance of a reducing balance in cells exposed to high concentrations of oxygen free radicals including erythrocytes, lens, and cornea of the eye and phagocytic cells [15].

G6PD was discovered in 1931 and was isolated in crystalline form by Noltmann and his coworkers from Brewer's yeast $[6,16]$. G6PD is found in animal tissues, plants, and microorganisms [11]. In animal tissues, the enzyme is localized in cytosol and mitochondria $[17,18]$ and in green plants in cytosol and chloroplasts $[1,5,15]$. G6PD is widespread in all tissues and blood cells and is a housekeeping enzyme [19]. G6PD is a significant cytosolic antioxidant enzyme, fundamental for maintenance of cytosolic redox status [20], and plays a critical role in cell growth and death $[6,21]$.

G6PD deficiency is a common enzymatic defect and leads to hemolysis in the presence of oxidative stress [22]; 
sufficient quantities of NADPH will not be formed and hydrogen ions will not be available to generate reduced glutathione. As a consequence, oxidative tissue damage may result. Particularly susceptible to oxidative injury is the red blood cell (RBC), as this cell does not have a mechanism other than G6PD of reducing NADP to NADPH [3]. G6PD is purified and identified from several sources including the hyperthermophilic bacterium Thermotoga maritima [23], Schizosaccharomyces pombe [24], nematodes [25], rabbit liver lumenal endoplasmic reticulum [18], mouse liver [26], dog liver [5], rat brain [27], peroxisomes from guinea pig small intestine [28], bovine lense [1], human placenta [12], buffalo erythrocyte [15], human erythrocyte [29], sheep kidney cortex [6], and rat kidney [30].

This study aims at purifying and characterizing G6PD from the camel liver. The ultimate goal of our study is enzyme production for medical and industrial applications. It is worthwhile to develop economical production method of G6PD from the locally available rich source to establish a continuous supply and quick delivery of different purity grades of the enzyme. Camel is one of the most common domestic mammals in Egypt, Arab world, and the Middle East area. Liver has been selected for the present study since it contains the highest G6PD activity.

\section{Materials and Methods}

2.1. Liver Material. Fresh liver samples of camel Camelus dromedarius were obtained from a local slaughterhouse and stored at $-40^{\circ} \mathrm{C}$. Liver samples were collected from at least six different animals.

2.2. Chemicals. Glucose-6-phosphate (G6P), $\beta$-Nicotinamide adenine dinucleotide phosphate $\left(\mathrm{NADP}^{+}\right), \beta$-Nicotinamide adenine dinucleotide phosphate, reduced (NADPH), 6-phosphogluconic acid (6PG), adenosine- $5^{\prime}$-triphosphate (ATP), adenosine diphosphate (ADP), $\beta$-Nicotinamide adenine dinucleotide (NAD), $\beta$-Nicotinamide adenine dinucleotide, reduced (NADH), DL-Dithiothreitol (DTT), nitroblue tetrazolium (NBT), phenazine methosulphate (PMS), blue dextran, bovine serum albumin (BSA), Sephacryl S-300, molecular weight marker kits for gel filtration, diethylaminoethyl-cellulose (DEAE-Cellulose), and chemicals for electrophoresis and isoelectric focusing (IEF) standard markers mixture $p \mathrm{I}$ 3.6-9.3 were purchased from Sigma Chemical Co. Molecular weight SDS marker proteins and $2^{\prime}, 5^{\prime}$ ADP Sepharose 4B were products of Pharmacia Fine Chemicals Co.

2.3. Assay of Glucose-6-Phosphate Dehydrogenase Activity. The G6PD activity assay was carried out according to the method described by Betke et al. [31] by monitoring the NADPH production spectrophotometrically at $340 \mathrm{~nm}$. The assay mixture contained $10 \mathrm{mM} \mathrm{MgCl}_{2}, 0.2 \mathrm{mM} \mathrm{NADP}^{+}$, and $0.6 \mathrm{mM}$ G6P in $100 \mathrm{mM}$ Tris/HCl buffer, $\mathrm{pH}$ 8.0, and was initiated by addition of the enzyme. One unit (U) of enzyme activity is the amount of enzyme required to reduce $1 \mu \mathrm{mol}$ of $\mathrm{NADP}^{+}$per minute.

\subsection{Purification of Glucose-6-Phosphate Dehydrogenase from Camel Liver}

2.4.1. Preparation of Crude Extract. Ten grams of liver was minced and homogenized by omnimixer (Sorvall Dupont Instruments), with two volumes ( $2 \mathrm{~mL} / \mathrm{gm}$ tissue) of $0.02 \mathrm{M}$ Tris/HCI buffer, $\mathrm{pH} 7.6$, containing $1 \mathrm{mM} \beta$ mercaptoethanol and $1 \mathrm{mM}$ EDTA on ice. The mixture was centrifuged at $12.000 \times \mathrm{g}$ for $30 \mathrm{~min}$ at $4^{\circ} \mathrm{C}$ and the pellet was discarded. The supernatant containing the enzyme activity was saved and designated the crude extract.

2.4.2. Ammonium Sulfate Precipitation. The crude extract was brought to $40 \%$ saturation by addition of solid ammonium sulfate and stirred for $30 \mathrm{~min}$ at $4^{\circ} \mathrm{C}$ and then centrifuged for $30 \mathrm{~min}$ at $12.000 \times \mathrm{g}$. Sufficient solid $\left(\mathrm{NH}_{4}\right)_{2} \mathrm{SO}_{4}$ was added to the supernatant to give a final saturation of $60 \%$. The pellet was obtained by centrifugation at $12000 \times \mathrm{g}$ for $30 \mathrm{~min}$ and dissolved in $0.02 \mathrm{M}$ Tris/HCI buffer, $\mathrm{pH}$ 7.6, containing $1 \mathrm{mM} \beta$-mercaptoethanol and $1 \mathrm{mM}$ EDTA and dialysed against the same buffer and designated ammonium sulfate fraction.

2.4.3. DEAE-Cellulose Column Chromatography. The dialyzed sample was chromatographed on DEAE-cellulose column $(12 \times 2.4 \mathrm{~cm}$ i.d. $)$ previously equilibrated with $0.02 \mathrm{M}$ Tris/HCI buffer, $\mathrm{pH}$ 7.6, containing $1 \mathrm{mM} \beta$-mercaptoethanol and $1 \mathrm{mM}$ EDTA. The adsorbed proteins were eluted with stepwise $\mathrm{NaCl}$ gradient ranging from 0 to $1 \mathrm{M}$ prepared in the equilibration buffer at a flow rate of $60 \mathrm{~mL} /$ hour and $5 \mathrm{~mL}$ fractions were collected. Fractions containing G6PD activity were pooled and lyophilized.

2.4.4. Sephacryl S-300 Column Chromatography. The DEAEcellulose concentrated solution containing the G6PD activity was applied onto a Sephacryl S-300 column $(142 \mathrm{~cm}$ $\times 1.75 \mathrm{~cm}$ i.d.). The column was equilibrated and developed with $0.02 \mathrm{M}$ Tris/HCI buffer, $\mathrm{pH}$ 7.6, containing $1 \mathrm{mM}$ $\beta$-mercaptoethanol and $1 \mathrm{mM}$ EDTA at a flow rate of $30 \mathrm{~mL} /$ hour and $2 \mathrm{~mL}$ fractions were collected and the fractions containing G6PD activity were pooled and lyophilized.

2.4.5. Chromatography on $2^{\prime}, 5^{\prime}$ ADP Sepharose $4 B$ Affinity Column. The Sephacryl S-300 concentrated fractions containing the G6PD activity were applied onto a $2^{\prime}, 5^{\prime} \mathrm{ADP}$ Sepharose $4 \mathrm{~B}$ affinity column $(3 \mathrm{~cm} \times 2.4 \mathrm{~cm}$ i.d. $)$ equilibrated with $0.02 \mathrm{M}$ Tris/HCI buffer, $\mathrm{pH} 7.6$, containing $1 \mathrm{mM} \beta$ mercaptoethanol and $1 \mathrm{mM}$ EDTA (Buffer A). The column was washed with the same buffer at a flow rate of $15 \mathrm{~mL} / \mathrm{h}$ to remove all the nonspecifically bound proteins. The G6DP was eluted with buffer A containing $0.5 \mathrm{mM} \mathrm{NADP}^{+}$.

2.5. Electrophoretic Analysis. Native gel electrophoresis was carried out using 7\% PAGE according to Smith [32]. SDSPAGE was performed with $12 \%$ polyacrylamide gel according to Laemmli [33]. The subunit molecular weight of the purified camel liver G6PD enzyme was determined using SDS-PAGE as described by Weber and Osborn [34]. Electrofocusing was performed according to O'Farrell [35] and the isoelectric 
TABLE 1: A typical purification scheme of camel liver G6PD.

\begin{tabular}{|c|c|c|c|c|c|}
\hline Purification steps ${ }^{*}$ & Total protein (mg) & Total activity $\left(\right.$ unit $^{\dagger}$ ) & Specific activity ${ }^{\ddagger}$ & Yield (\%) & Fold purification \\
\hline Crude extract & 156.28 & 4.4801 & 0.0286 & 100 & 1.00 \\
\hline Ammonium sulphate fraction & 49.530 & 3.8517 & 0.0777 & 85.97 & 2.719 \\
\hline \multicolumn{6}{|l|}{ DEAE-cellulose } \\
\hline Camel liver G6PD (0.1 M NaCl) & 18.032 & 3.0527 & 0.16929 & 68.13 & 5.919 \\
\hline \multicolumn{6}{|l|}{ Sephacryl S-300 } \\
\hline Camel liver G6PD & 9.7562 & 2.5990 & 0.26647 & 58.01 & 9.317 \\
\hline \multicolumn{6}{|l|}{$2^{\prime}, 5^{\prime}$ ADP Sepharose 4B } \\
\hline Camel liver G6PD & 1.2320 & 2.2230 & 1.80438 & 49.61 & 63.09 \\
\hline
\end{tabular}

* All data is based on $10 \mathrm{gm}$ camel liver.

${ }^{\dagger}$ One unit of glucose-6-phosphate dehydrogenase enzyme activity is identified as the amount of enzyme required to reduce $1 \mu \mathrm{mol}$ of $\mathrm{NADP}^{+}$per minute.

${ }^{\ddagger}$ Specific activity is expressed as units/mg protein.

point $(p \mathrm{I})$ values were calculated from a calibration curve as described by Ubuka et al. [36]. Proteins were stained with $0.25 \%$ coomassie brilliant blue R-250.

2.6. Protein Quantification. Protein was quantified by the dye binding assay method of Bradford [37] using BSA as a standard protein.

\section{Results}

3.1. Purification of Glucose-6-Phosphate Dehydrogenase from Camel Liver. The G6PD specific activity of camel liver crude extract was found to be $0.0286 \mathrm{unit} / \mathrm{mg}$ protein. A typical purification scheme of G6PD from the camel liver is presented in Table 1 . After ammonium sulfate precipitation, most of the glucose-6-phosphate dehydrogenase activity was precipitated; $85.97 \%$ of the activity was recovered. The DEAEcellulose elution profile (Figure 1) revealed the presence of one major peak containing G6PD activity eluted with $0.1 \mathrm{M} \mathrm{NaCl}$ and designated camel liver G6PD. The DEAEcellulose fractions were pooled, concentrated by lyophilization, and applied onto a Sephacryl S-300 column. The elution profile of camel liver G6PD on the Sephacryl S300 column (Figure 2) revealed the presence of one peak of the enzyme activity. The specific activity of CLG6PD was increased to 0.26647 units/mg protein, which represent 9.317fold purification over the crude extract with $58.01 \%$ yield. The Sephacryl S-300 fractions were pooled, concentrated by lyophilization, and applied onto $2^{\prime}, 5^{\prime}$ ADP Sepharose 4B Affinity column (Figure 3 ). The specific activity of camel liver G6PD was increased to 1.80438 units/mg protein, which represent 63.09-fold purification over the crude extract with $49.61 \%$ yield (Table 1 ).

3.2. Molecular Weight Determination by Gel Filtration. Camel liver G6PD was eluted at $176 \mathrm{~mL}$ from Sephacryl S-300 column and its native molecular weight was deduced to be $194 \pm 2.3 \mathrm{kDa}$.

3.3. Electrophoretic Analyses of Camel Liver G6PD. Samples from the different purification steps, crude extract, ammonium sulfate fraction, DEAE-cellulose fraction, Sephacryl

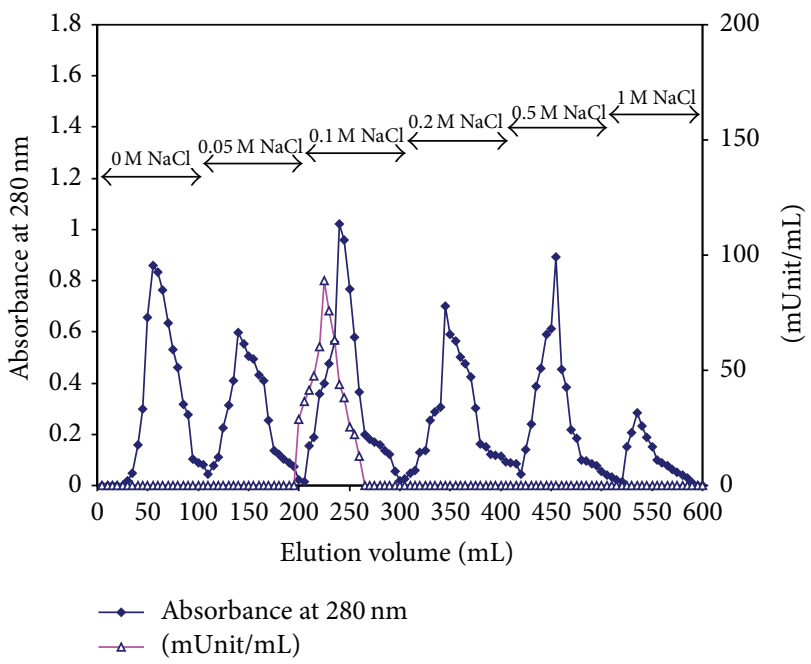

Figure 1: A typical elution profile for the chromatography of the camel liver ammonium sulfate fraction on DEAE-cellulose column $(12 \mathrm{~cm} \times 2.4 \mathrm{~cm})$ previously equilibrated with $0.02 \mathrm{M}$ Tris $/ \mathrm{HCI}$ buffer, pH 7.6 containing $1 \mathrm{mM} \beta$-mercaptoethanol, and $1 \mathrm{mM}$ EDTA. The proteins were eluted by a stepwise gradient of $\mathrm{NaCl}$ ranging from 0 to $1 \mathrm{M}$ in the equilibration buffer. $5 \mathrm{~mL}$ fractions were collected at a flow rate of $60 \mathrm{~mL} / \mathrm{h}$.

S-300 fraction, and $2^{\prime}, 5^{\prime}$ ADP Sepharose $4 \mathrm{~B}$ fraction of camel liver G6PD were analyzed electrophoretically on 7\% native PAGE (Figure 4(a)). Single protein bands coincided with the enzyme activity bands indicating the tentative purity of the enzyme preparation (Figure 4(b)). Electrophoretic analysis of denatured purified camel liver G6PD enzyme on SDS-PAGE was compared with molecular weight marker proteins; the subunit molecular weight was calculated to be $64 \pm 1.48 \mathrm{kDa}$ (Figure $4(\mathrm{c})$ ). The purified camel liver G6PD was electrofocused and the isoelectric point $(p I)$ value was calculated. Camel liver G6PD enzyme showed a single molecular species with $p$ I value of 6.6-6.8 (Figure 4(d)).

3.4. Determination of Optimum $p H$. The effect of $\mathrm{pH}$ on the camel liver G6PD activity was examined in $0.02 \mathrm{M}$ Tris/HCI 


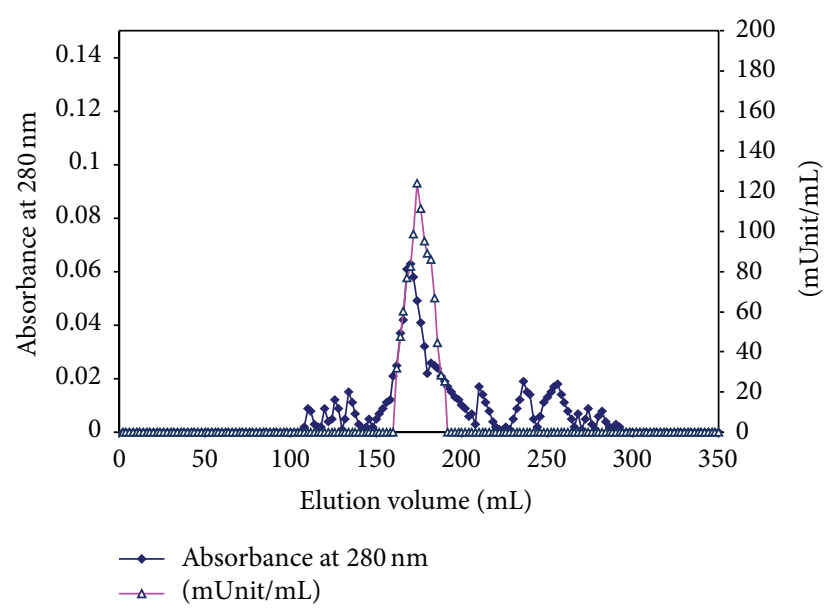

FIGURE 2: A typical elution profile for the chromatography of the concentrated pooled DEAE-cellulose fractions containing (camel liver G6PD) activity on Sephacryl S-300 column $(142 \mathrm{~cm} \times 2.4 \mathrm{~cm})$ previously equilibrated with $0.02 \mathrm{M}$ Tris/HCI buffer, $\mathrm{pH} 7.6$ containing $1 \mathrm{mM} \beta$-mercaptoethanol, and $1 \mathrm{mM}$ EDTA. The proteins were eluted by the same buffer. $2 \mathrm{~mL}$ fractions were collected at a flow rate of $30 \mathrm{~mL} / \mathrm{h}$.

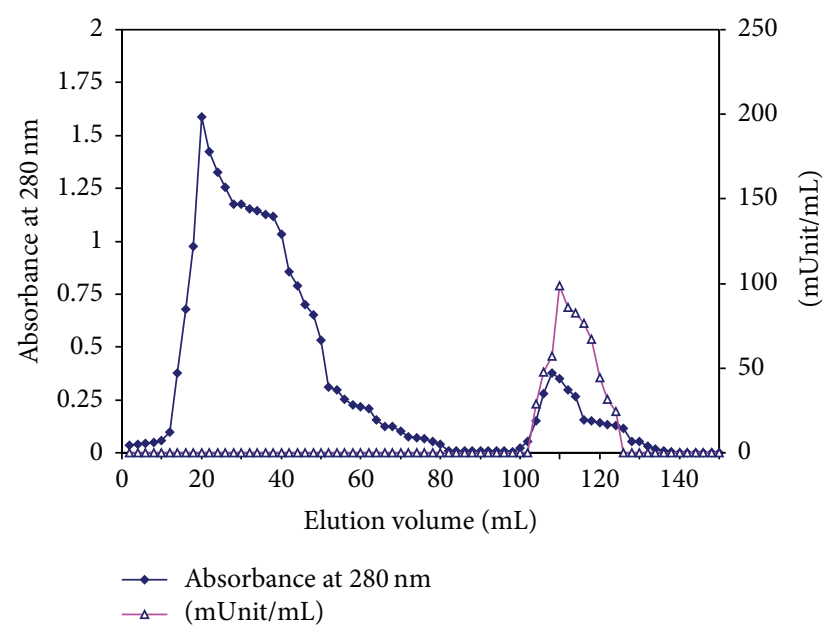

FIGURE 3: A typical elution profile for the chromatography of the concentrated pooled Sephacryl S-300 column fractions containing (camel liver G6PD) activity on $2^{\prime}, 5^{\prime}$ ADP Sepharose 4B column $(3 \mathrm{~cm} \times 2.4 \mathrm{~cm})$ previously equilibrated with $0.02 \mathrm{M}$ Tris/HCI buffer, $\mathrm{pH} 7.6$ containing $1 \mathrm{mM} \beta$-mercaptoethanol, and $1 \mathrm{mM}$ EDTA (buffer A). The proteins were eluted by the same buffer containing $0.5 \mathrm{mM} \mathrm{NADP}{ }^{+} .2 \mathrm{~mL}$ fractions were collected at a flow rate of $15 \mathrm{~mL} / \mathrm{h}$.

buffer, $\mathrm{pH}$ (5.2-8.8). The $\mathrm{pH}$ profile of camel liver G6PD displayed its optimum activity at pH 7.8 (Figure 5).

3.5. Effect of Divalent Cations. The purified camel liver G6PD was preincubated with $2 \mathrm{mM}$ and $5 \mathrm{mM}$ of each cation at $37^{\circ} \mathrm{C}$ and the activity was assayed. A control test without any cation was taken as $100 \%$ relative activity. The activity of the camel liver G6PD is increased about 1.28-, 1.17-, and 1.07-fold in the presence of $2 \mathrm{mM} \mathrm{MgCl}_{2}, \mathrm{MnCl}_{2}$, and $\mathrm{CoCl}_{2}$, respectively, and increased about 1.37-, 1.21-, and 1.10-fold in the presence of $5 \mathrm{mM} \mathrm{MgCl}_{2}, \mathrm{MnCl}_{2}$, and $\mathrm{CoCl}_{2}$, respectively. In contrast, $\mathrm{CaCl}_{2}$ and $\mathrm{NiCl}_{2}$ were found to be moderate inhibitors of camel liver G6PD activity while $\mathrm{FeCl}_{2}, \mathrm{CuCl}_{2}$, and $\mathrm{ZnCl}_{2}$ are potent inhibitors of camel liver G6PD (Figure 6).

3.6. Michaelis-Menten Constant $\left(K_{m}\right)$ Value. The $K_{m}$ value of camel liver G6PD was found to be $0.081 \mathrm{mM} \mathrm{NADP}^{+}$and the corresponding maximum velocity $\left(V_{\max }\right)$ was calculated to be 1875.86 munits/mg protein (Figure $7(a)$ ). For further confirmation, a Lineweaver-Burk plot for the reciprocal of the reaction velocity $(1 / V)$ and substrate concentration $(1 /[S])$ was constructed; the $K_{m}$ value of camel liver G6PD was deduced to be $0.081 \mathrm{mM} \mathrm{NADP}^{+}$(Figure $7(\mathrm{~b})$ ).

3.7. Effect of Various Inhibitors. The purified camel liver G6PD is preincubated with $2 \mathrm{mM}$ and $5 \mathrm{mM}$ of each inhibitor $(0.1 \mathrm{mM}$ and $0.2 \mathrm{mM}$ of $\mathrm{NADPH})$ for $5 \mathrm{~min}$ at $37^{\circ} \mathrm{C}$ and the residual activity was calculated as a ratio of a control lacking inhibitor. NADPH is found to be the most potent inhibitor of the camel liver G6PD activity (Figure 8).

3.8. Kinetics of Camel Liver G6PD Inhibition by NADPH. The NADPH exhibited the most potent inhibitory effect on the camel liver G6PD. The effect of varying concentrations of NADPH on the camel liver G6PD activity presented in (Figure 9(a)). A maximum inhibition of camel liver G6PD by NADPH was found to be $87.88 \%$ at $0.17 \mathrm{mM}$ of NADPH. In the Hill plot, when $\log V_{i} / V_{\max }-V_{i}$ values were plotted against $\log [I]$ values of the NADPH, a straight line was obtained with slope of about 0.88 for camel liver G6PD indicating the presence of one binding site for NADPH in camel liver G6PD (Figure 9(b)). The type of inhibition of camel liver G6PD by NADPH is competitive type since the presence of the inhibitor did not alter the $V_{\max }$ value but it increases the $K_{m}$ value (Figure 10(a)). The $K_{i}$ value of the camel liver G6PD inhibition by NADPH is determined to be $0.035 \mathrm{mM}$ (Figure 10(b)).

\section{Discussion}

G6PD plays a significant role in maintaining the level of $\mathrm{NADPH}$ and in generating pentose phosphates for nucleotide biosynthesis $[2,38]$. In this study, a simple and reproducible purification method for G6PD from camel liver was used. Camel is one of the most common domestic mammals in Egypt, Arab world, and the Middle East area. The purification procedure was carried out by ammonium sulfate precipitation, ion exchange chromatography on DEAEcellulose column, gel filtration chromatography on Sephacryl S-300 column, and affinity chromatography on $2^{\prime}, 5^{\prime}$ ADP Sepharose 4B column. Similar purification procedures of G6PDs were reported from mouse liver [26], from dog liver [5], from bovine lens [1], from human placental [12], from human erythrocyte [29], from sheep kidney cortex [6], and from rat kidney [30]. 


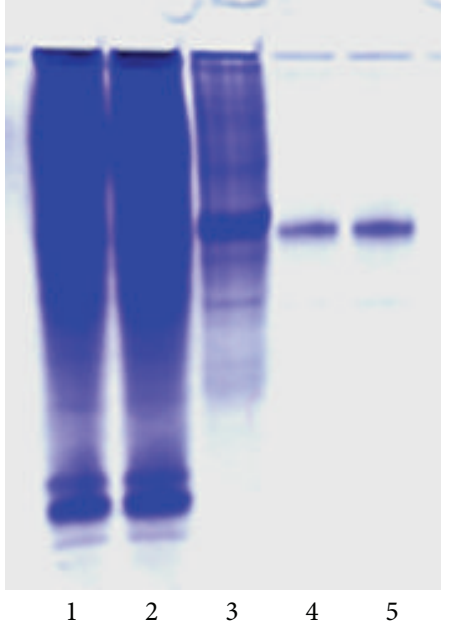

(a) Protein pattern

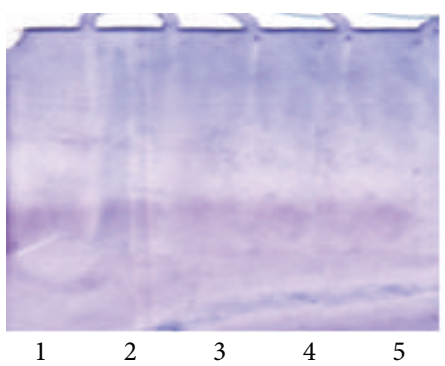

(b) Enzyme activity pattern

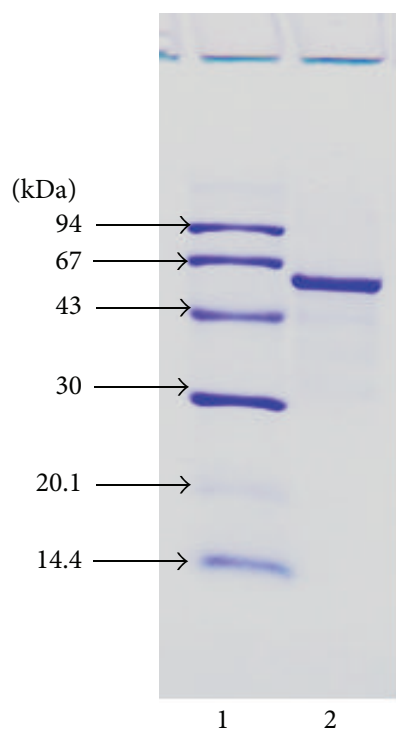

(c) SDS PAGE

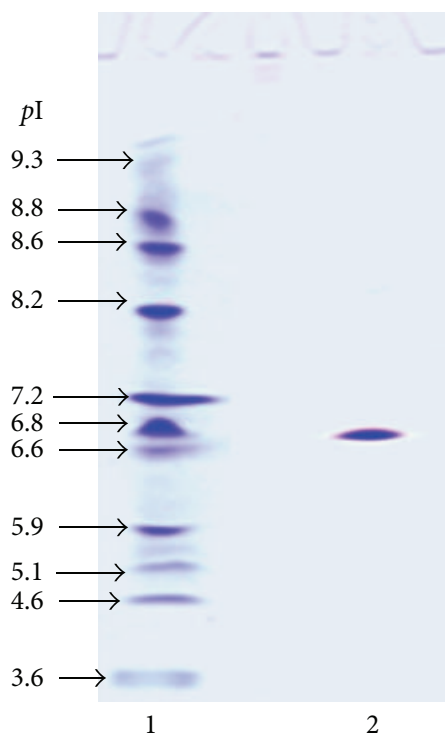

(d) $p \mathrm{I}$

FIGURE 4: Electrophoretic analysis of (camel liver G6PD) the different purification steps on 7\% native polyacrylamide gel. (a) Protein pattern: (1) crude extract, (2) ammonium sulfate fraction, (3) $0.1 \mathrm{M}$ DEAE-cellulose fraction, (4) Sephacryl S-300 purified fraction, and (5) $2^{\prime}, 5^{\prime}$ ADP Sepharose 4B fractions. (b) Enzyme pattern: (1) crude extract, (2) ammonium sulfate fraction, (3) 0.1 M DEAE-cellulose fraction, (4) Sephacryl S-300 purified fraction, and (5) 2', $5^{\prime}$ ADP Sepharose 4B fractions. (c) Subunit molecular weight determination by electrophoretic analysis of camel liver G6PD on 12\% SDS-polyacrylamide gel: (1) molecular weight marker proteins and (2) purified camel liver glucose-6phosphate dehydrogenase enzyme camel liver G6PD. (d) Isoelectrofocusing: (1) isoelectric point ( $p I$ ) marker proteins and (2) the purified camel liver glucose-6-phosphate dehydrogenase camel liver G6PD.

The chromatography on the DEAE-cellulose column revealed that the camel liver G6PD is moderate, negatively charged, and moderately bound to the DEAE-cellulose matrix since it was eluted with $0.1 \mathrm{M} \mathrm{NaCl}$ (Figure 1). The camel liver G6PD was eluted from the Sephacryl S-300 column as a single enzyme activity peak and the deduced molecular mass was found to be $194 \pm 2.3 \mathrm{kDa}$ (Figure 2). The camel liver G6PD was eluted from the $2^{\prime}, 5^{\prime}$ ADP Sepharose $4 \mathrm{~B}$ column as a single enzyme activity peak (Figure 3 ). The specific activity of camel liver G6PD was increased to 1.80438 units/mg protein, which represent 63.09 -fold purification over the crude extract with $49.61 \%$ yield. A large variety of purification fold and recovery percent for G6PD were reported: mouse liver with $8.7 \%$ yield [26], dog liver with $18 \%$ yield [5], bovine lens 19.7-fold with $13.7 \%$ yield [1], human placenta with $62 \%$ yield [12], human erythrocyte 91.50 -fold with $43 \%$ yield [29], and sheep kidney cortex 13.84 -fold with $16.96 \%$ yield [6]. 


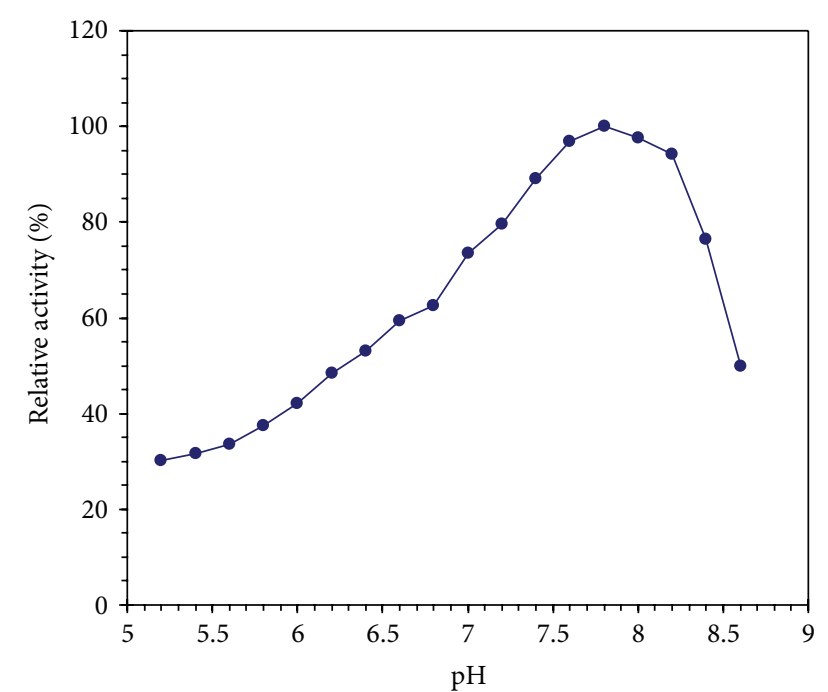

FIgURe 5: Effect of $\mathrm{pH}$ on camel liver G6PD using 0.02 M Tris/HCI buffer of various $\mathrm{pH}$ values.

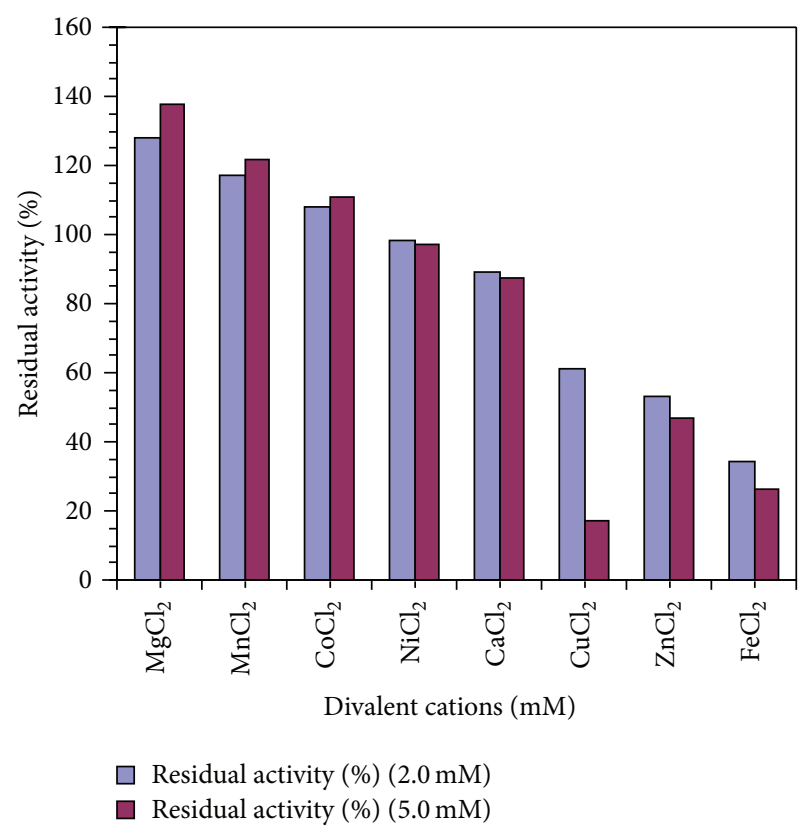

FIGURE 6: Effect of divalent cations on the purified camel liver G6PD.

The purity of camel liver G6PD eluted from the $2^{\prime}$, $5^{\prime}$ ADP Sepharose 4B column was investigated by analysis on $7 \%$ native PAGE. Camel liver G6PD turned out to be homogeneous preparation indicating the tentative purity of the enzyme; also the protein band coincided with the enzyme activity band confirming that the single protein band is the enzyme band (Figures 4(a) and 4(b)). The subunit molecular weight of camel liver G6PD was determined by SDS-PAGE to be $64 \pm 1.48 \mathrm{kDa}$ (Figure 4(c)). Comparison of subunit molecular weight with that of native intact protein determined by gel filtration indicated that camel liver G6PD is trimeric protein composed of three identical subunits. Distinct G6PD molecular weights were reported from different organism, tissues, and organs. Many G6PDs were reported to have a monomeric structure with subunit molecular weight of $62 \mathrm{kDa}$ as that of bovine lens [1], $54 \mathrm{kDa}$ of human placenta [12], and $52 \mathrm{kDa}$ of dog liver [5]. A dimeric structure was reported for G6PD from rat kidney with a native molecular mass of $144 \mathrm{kDa}$ and subunit molecular mass of $68 \mathrm{kDa}$ [30]. A tetrameric structure was reported for G6PD from mouse liver with a native and subunit molecular weight of 117 and $31 \mathrm{kDa}$, respectively [26].

The isoelectric point $(p I)$ value was estimated for the purified camel liver G6PD at 6.6-6.8 (Figure 4(d)). Lower isoelectric points $(p \mathrm{I})$ value was reported for G6PD from bovine lens at 5.14 [1]. The camel liver G6PD displayed the optimum $\mathrm{pH}$ at 7.8 (Figure 5). Similarly, the $\mathrm{pH}$ optimum was determined to be 7.8 for G6PD from human placenta [12]. Dog liver G6PD had a pH optimum of 7.8 [5]. The optimum $\mathrm{pH}$ of the lamb kidney cortex G6PD was determined to be between $\mathrm{pH} 7.6$ and 7.8 [39]. The optimum $\mathrm{pH}$ of the sheep kidney cortex G6PD was determined to be $\mathrm{pH} 7.4$ [6].

$\mathrm{FeCl}_{2}, \mathrm{CuCl}_{2}, \mathrm{CoCl}_{2}$, and $\mathrm{ZnCl}_{2}$ inhibited the activity of camel liver G6PD while $\mathrm{MnCl}_{2}$ and $\mathrm{MgCl}_{2}$ increased the activity of the camel liver G6PD (Figure 6). These results are in accordance with G6PD of rainbow trout liver (Oncorhynchus mykiss) which is inhibited by $\mathrm{FeCl}_{2}, \mathrm{CuCl}_{2}$, and $\mathrm{ZnCl}_{2}[40]$.

The $K_{m}$ value of the purified camel liver G6PD was found to be $0.081 \mathrm{mM} \beta$-Nicotinamide adenine dinucleotide phosphate $\left(\mathrm{NADP}^{+}\right)$with a maximum velocity of 1875.86 munits/mg protein (Figure 7) indicating the high affinity of the purified G6PD toward the $\mathrm{NADP}^{+}$. This value is considerably close to G6PD from rat liver, since $K_{m}$ value was found to be $0.100 \mathrm{mM} \mathrm{NADP}^{+}$. Different $K_{m}$ values were reported; $K_{m}$ value was found to be $0.025 \mathrm{mM}$ NADP for G6PD of rat kidney cortex [41], that of bovine lens was $0.008 \mathrm{mM}$ [1], that of human placenta was $0.020 \mathrm{mM}$ [12], that of dog liver was $0.010 \mathrm{mM}$ [5], and that of sheep kidney cortex was $0.0147 \mathrm{mM}[6]$.

In this study, the effect of different specific and characteristic inhibitors on the camel liver G6PD is presented in (Figure 8). NADPH is found to be the most potent inhibitor of the activity of camel liver G6PD since $0.1 \mathrm{mM}$ NADPH inhibited the camel liver G6PD activity $69.70 \%$ while $0.2 \mathrm{mM}$ NADPH inhibited the camel liver G6PD activity 90.91\%. 6Phosphogluconic acid, ATP, ADP, and NADH were found to be weak inhibitors of camel liver G6PD activity. NAD has no inhibitory effect on the activity of camel liver G6PD. Similarly, G6PD from mouse liver [26], bovine lens [1], human placenta [12], dog liver [5], human erythrocyte [29], sheep kidney cortex [6], and rat kidney [30] were inhibited by NADPH.

The effect of NADPH concentration on the purified camel liver G6PD indicated that a maximum inhibition of camel liver G6PD by NADPH was found to be $87.88 \%$ at $0.17 \mathrm{mM}$ of NADPH (Figure 9(a)). However, full explanation of these data required knowledge of the number of inhibitor molecules bound per enzyme molecule. A linear relationship was observed by constructing the Hill plot for the inhibition 


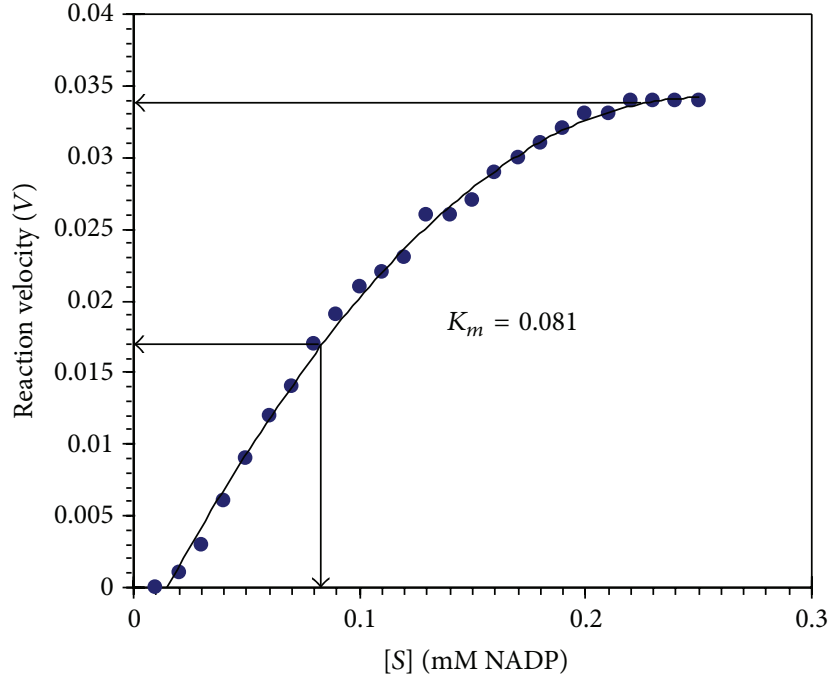

(a)

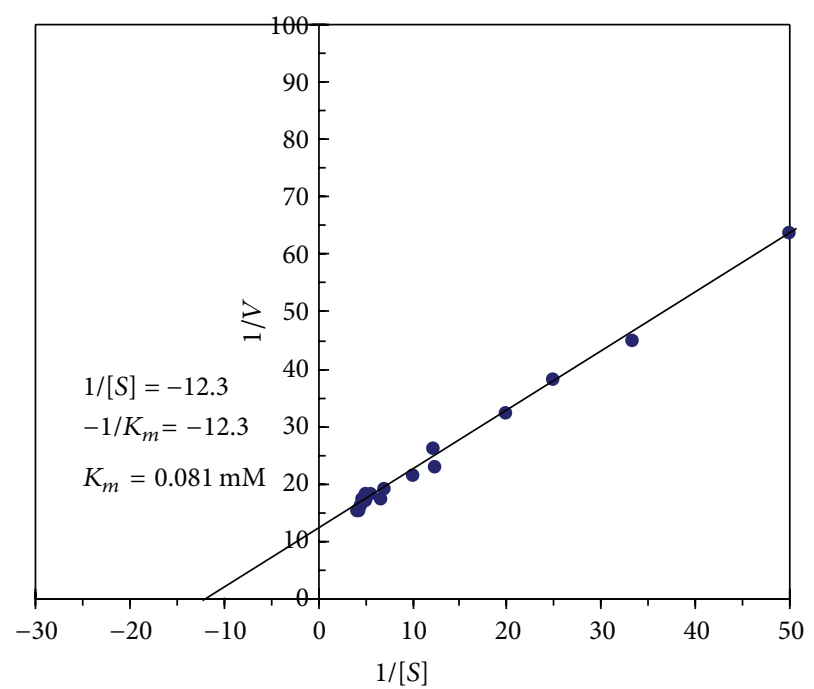

(b)

FIGURE 7: (a) Effect of the substrate $\beta$-Nicotinamide adenine dinucleotide phosphate $\left(\mathrm{NADP}^{+}\right)$concentration in $\mathrm{mM}$ on the reaction velocity of camel liver G6PD. The reaction velocity is the change in absorbance at $340 \mathrm{~nm}$ per $60 \mathrm{~min}$. (b) Lineweaver-Burk plot relating the reciprocal of the reaction velocity of camel liver G6PD to $\left(\mathrm{NADP}^{+}\right)$concentration in $\mathrm{mM}$.

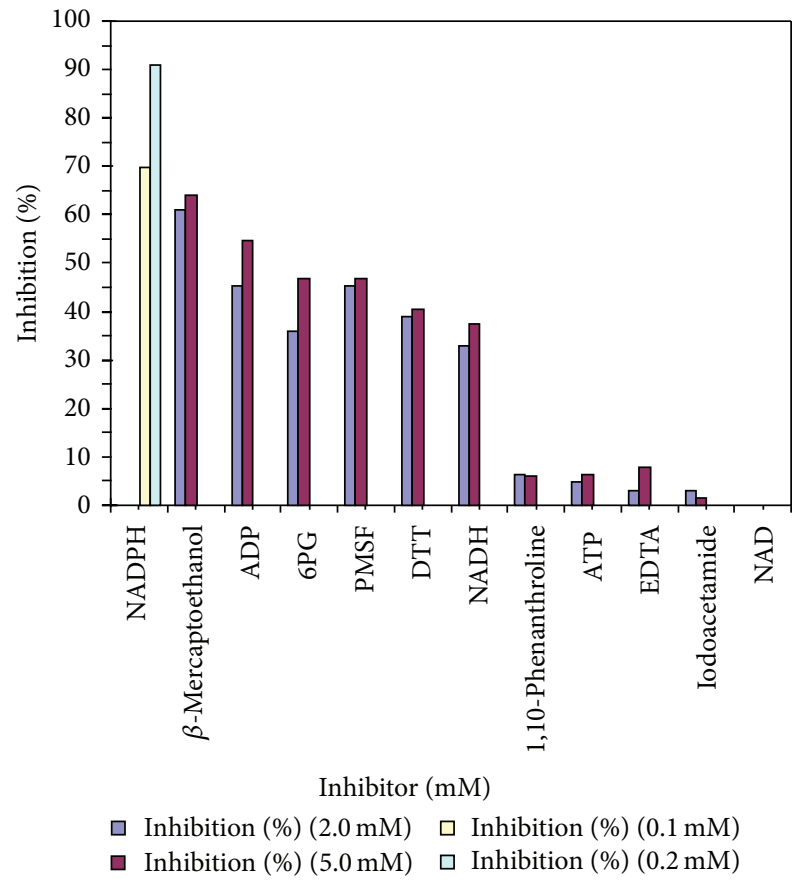

Figure 8: Effect of inhibitors on purified camel liver G6PD.

of the purified camel liver G6PD by NADPH (Figure 9(b)). The slope of the Hill plot was found to be 0.88 for camel liver G6PD indicating the existence of one binding site for $\mathrm{NADPH}$ on camel liver G6PD. The type of inhibition of the purified camel liver G6PD by NADPH was found to be competitive (Figure 10(a)), where the presence of NADPH did not alter the $V_{\max }$ value but increased the $K_{m}$ value. For the determination of the $K_{i}$ value, the slopes of the reciprocal plots lines (Figure 10(a)) were plotted against the NADPH concentration (Figure 10(b)). The $K_{i}$ value of the enzyme inhibition by NADPH is determined to be $0.035 \mathrm{mM}$ directly from the intercept of the $x$-axis of the plot. Similarly, the $K_{i}$ value of the G6PD from bovine lens was found to be $0.017 \mathrm{mM}$ NADPH [1] and from dog liver $0.012 \mathrm{mM}$ [5].

$\beta$-Mercaptoethanol and dithiothreitol inhibited the camel liver G6PD indicating that SH groups in the active site play an important role for camel liver G6PD activity. Phenyl methyl sulfonyl fluoride inhibited camel liver G6PD indicating that serine residue is involved in the active site of the enzyme (Figure 8).

In conclusion, this study presents a simple and convenient method for the purification of glucose-6-phosphate dehydrogenase from camel liver as a rich source. The method is adaptable for large amounts of production of the enzymes by scaling up from the laboratory level to the larger scales. The characterization of the purified glucose-6-phosphate dehydrogenase established the optimum conditions for the activity of this enzyme and will allow their uses in various applications with maximum efficiency.

\section{Abbreviations}

BSA: Bovine serum albumin

PAGE: Polyacrylamide gel electrophoresis

NBT: Nitroblue tetrazolium

PMS: $\quad$ Phenazine methosulphate

PPP: $\quad$ Pentose phosphate pathway

$\mathrm{NADP}^{+}: \beta$-Nicotinamide adenine dinucleotide phosphate 


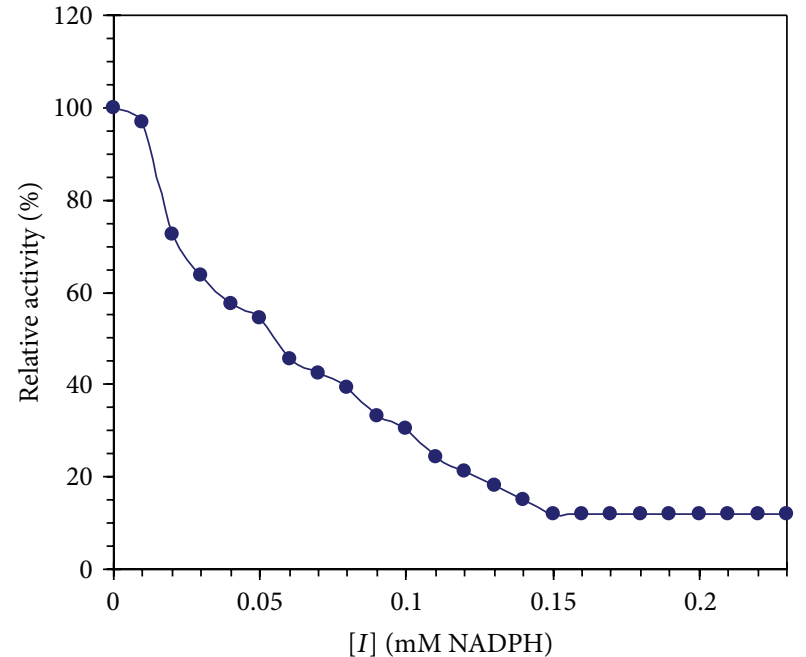

(a)

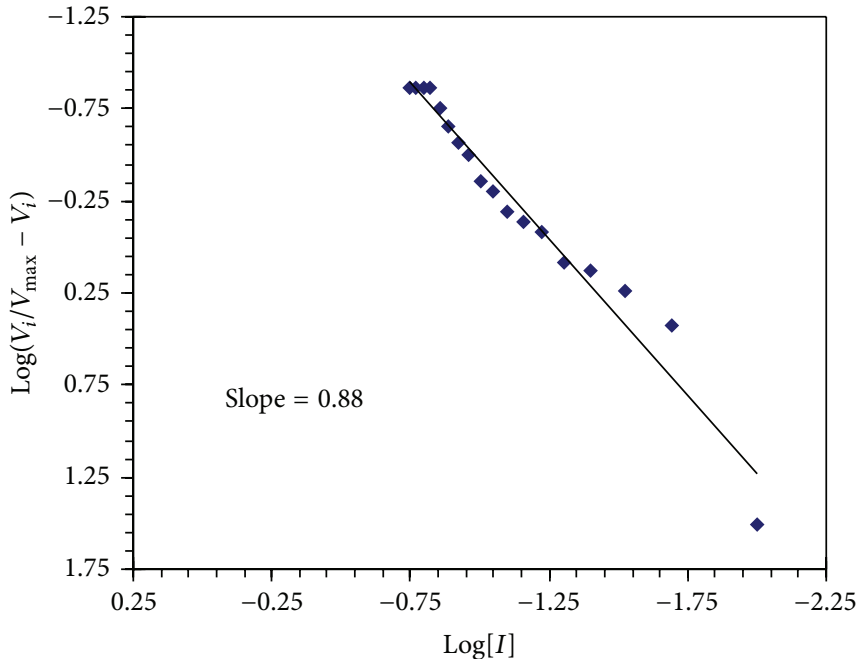

(b)

FIGURE 9: (a) Inhibition of camel liver G6PD by varying concentrations of NADPH. (b) Hill plot for inhibition of camel liver G6PD by varying concentrations of NADPH where $V_{\max }$ is the enzyme activity in absence of inhibitor. $V_{i}$ is the enzyme activity in presence of inhibitor and $[I]$ is inhibitor concentration in $\mathrm{mM}$ of NADPH.

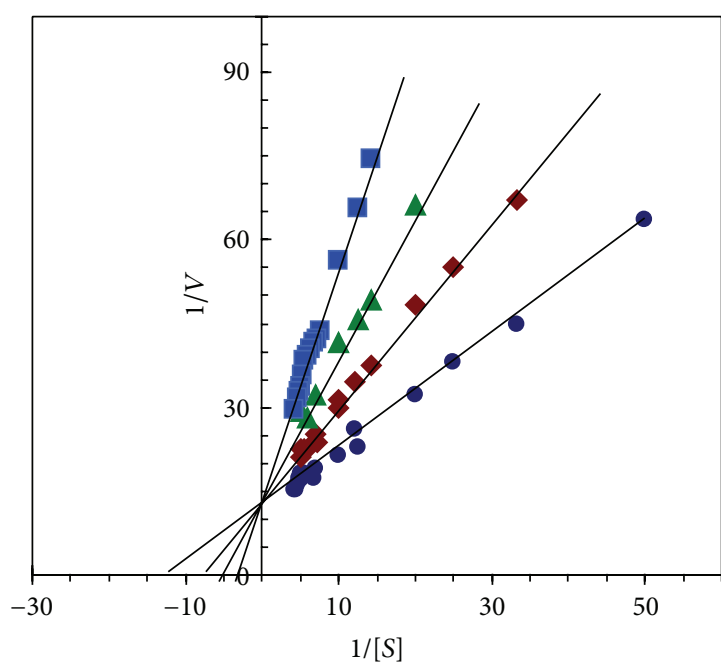

- $0 \mu \mathrm{M}$ NADPH

- $30 \mu \mathrm{M} \mathrm{NADPH}$
॥ $60 \mu \mathrm{M}$ NADPH

- $100 \mu \mathrm{M}$ NADPH

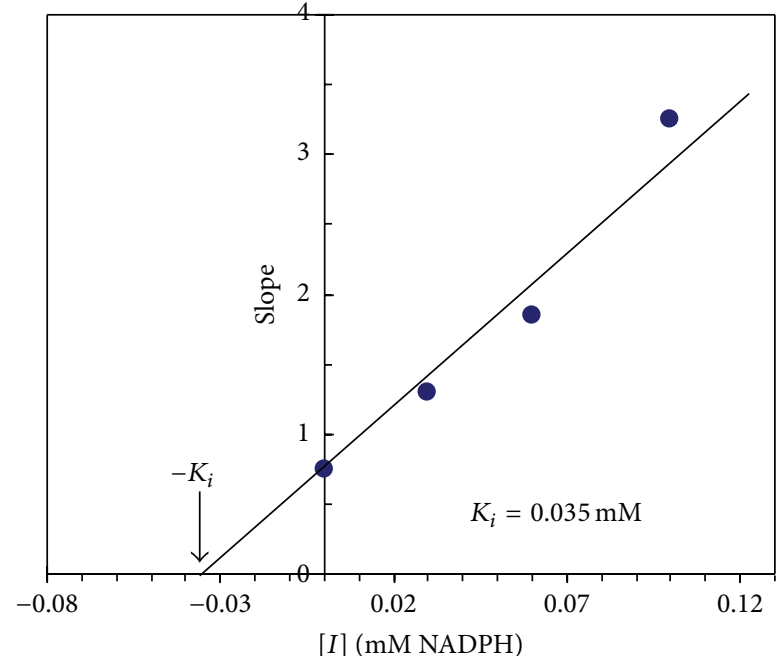

[I] (mM NADPH)

FIGURE 10: (a) Lineweaver-Burk plots showing the type of inhibition of camel liver G6PD by NADPH. The activity of camel liver G6PD was measured with varying concentrations of the substrate $\left(\mathrm{NADP}^{+}\right)$in absence and presence of three various concentrations of NADPH. (b) Determination of the inhibition constant $\left(K_{i}\right)$ value for the inhibition of camel liver G6PD by NADPH. The plotted slope values were determined from the lines of the reciprocal plots of the different inhibitor concentrations.

NADPH: Reduced $\beta$-Nicotinamide adenine dinucleotide phosphate

G6PD: Glucose-6-phosphate dehydrogenase.

\section{Conflict of Interests}

The authors declare that there is no conflict of interests regarding the publication of this paper.

\section{References}

[1] N. N. Ulusu, M. S. Kus, N. L. Acan, and E. F. Tezcan, "A rapid method for the purification of glucose-6-phosphate dehydrogenase from bovine lens," International Journal of Biochemistry and Cell Biology, vol. 31, no. 7, pp. 787-796, 1999.

[2] K. Winiarska, J. Drozak, M. Wegrzynowicz, A. K. Jagielski, and J. Bryła, "Relationship between gluconeogenesis and glutathione 
redox state in rabbit kidney-cortex tubules," Metabolism, vol. 52, no. 6, pp. 739-746, 2003.

[3] M. Kaplan and C. Hammerman, "Glucose-6-phosphate dehydrogenase deficiency and severe neonatal hyperbilirubinemia: a complexity of interactions between genes and environment," Seminars in Fetal and Neonatal Medicine, vol. 15, no. 3, pp. 148156, 2010.

[4] J. S. M. Del Campo and R. Patiño, "Kinetic and thermodynamic study of the reaction catalyzed by glucose-6-phosphate dehydrogenase with nicotinamide adenine dinucleotide," Thermochimica Acta, vol. 517, no. 1-2, pp. 40-44, 2011.

[5] N. Özer, C. Bilgi, and I. H. Ögüs, "Dog liver glucose-6phosphate dehydrogenase: purification and kinetic properties," The International Journal of Biochemistry \& Cell Biology, vol. 34, no. 3, pp. 253-262, 2002.

[6] N. N. Ulusu and B. Tandogan, "Purification and kinetics of sheep kidney cortex glucose-6-phosphate dehydrogenase," Comparative Biochemistry and Physiology $-B$ Biochemistry and Molecular Biology, vol. 143, no. 2, pp. 249-255, 2006.

[7] E. Beutler, "Glucose-6-phosphate dehydrogenase deficiency and other enzyme abnormalities," in Williams Hematology, E. Beutler, M. A. Lichtman, B. S. Coller, and T. J. Kipps, Eds., pp. 564-581, McGraw-Hill, New York, NY, USA, 5th edition, 1995.

[8] M. Ciftci, D. Bilici, and O. I. Kufrevioglu, "Effects of melatonin on enzyme activities of glucose-6-phosphate dehydrogenase from human erythrocytes in vitro and from rat erythrocytes in vivo," Pharmacological Research, vol. 44, no. 1, pp. 7-11, 2001.

[9] A. L. Lehninger, D. L. Nelson, and M. M. Cox, "Glycolysis, gluconeogenesis and the pentose phosphate pathway," in Principles of Biochemistry, pp. 558-560, Worth Publishers, New York, NY, USA, 2nd edition, 2000.

[10] M. Çiftçi, I. Özmen, M. E. Büyükokuroğlu, S. Pençe, and Ö. I. Küfrevioğlu, "Effects of metamizol and magnesium sulfate on enzyme activity of glucose 6-phosphate dehydrogenase from human erythrocyte in vitro and rat erythrocyte in vivo," Clinical Biochemistry, vol. 34, no. 4, pp. 297-302, 2001.

[11] H. R. Levy, "Glucose-6-phosphate dehydrogenases," in Advances in Enzymology, A. Meister, Ed., vol. 48, p. 97, John Wiley \& Sons, New York, NY, USA, 1979.

[12] Y. Aksoy, I. H. Ögüs, and N. Öauzer, "Purification and some properties of human placental glucose-6-phosphate dehydrogenase," Protein Expression and Purification, vol. 21, no. 2, pp. 286-292, 2001.

[13] R. Matsui, S. Xu, K. A. Maitland et al., "Glucose-6 phosphate dehydrogenase deficiency decreases the vascular response to angiotensin II," Circulation, vol. 112, no. 2, pp. 257-263, 2005.

[14] Y. Huang, M. Y. Choi, S. W. N. Au, D. M. Y. Au, V. M. S. Lam, and P. C. Engel, "Purification and detailed study of two clinically different human glucose 6-phosphate dehydrogenase variants, G6PDPlymouth and G6PDMahidol: evidence for defective protein folding as the basis of disease," Molecular Genetics and Metabolism, vol. 93, no. 1, pp. 44-53, 2008.

[15] M. Çiftçi, Ş. Beydemir, H. Yilmaz, and S. Altikat, "Purification of glucose 6-phosphate dehydrogenase from buffalo (Bubalus bubalis) erythrocytes and investigation of some kinetic properties," Protein Expression and Purification, vol. 29, no. 2, pp. 304310, 2003.

[16] E. A. Noltmann, C. J. Gubler, and S. A. Kuby, "Glucose 6phosphate dehydrogenase (Zwischenferment). I. Isolation of the crystalline enzyme from yeast," The Journal of Biological Chemistry, vol. 236, pp. 1225-1230, 1961.
[17] M. Grunwald and H. Z. Hill, "Characterization of the glucose 6 phosphate dehydrogenase activity in rat liver mitochondria," Biochemical Journal, vol. 159, no. 3, pp. 683-687, 1976.

[18] J. Ozols, "Isolation and the complete amino acid sequence of lumenal endoplasmic reticulum glucose-6-phosphate dehydrogenase," Proceedings of the National Academy of Sciences of the United States of America, vol. 90, no. 11, pp. 5302-5306, 1993.

[19] G. T. Yüregir, K. Aksoy, A. Arpaci, I. Unlukurt, and A. Tuli, "Studies on red cell glucose-6-phosphate dehydrogenase: evaluation of reference values," Annals of Clinical Biochemistry, vol. 31, no. 1, pp. 50-55, 1994.

[20] M. Jain, D. A. Brenner, L. Cui et al., "Glucose-6-phosphate dehydrogenase modulates cytosolic redox status and contractile phenotype in adult cardiomyocytes," Circulation Research, vol. 93, no. 2, p. -16, 2003.

[21] W.-N. Tian, L. D. Braunstein, J. Pang et al., "Importance of glucose-6-phosphate dehydrogenase activity for cell growth," The Journal of Biological Chemistry, vol. 273, no. 17, pp. 1060910617, 1998.

[22] G. Dhaliwal, P. A. Cornett, and L. M. Tierney Jr., "Hemolytic anemia," American Family Physician, vol. 69, no. 11, pp. 25992606, 2004.

[23] T. Hansen, B. Schlichting, and P. Schönheit, "Glucose-6phosphate dehydrogenase from the hyperthermophilic bacterium Thermotoga maritima: expression of the g6pd gene and characterization of an extremely thermophilic enzyme," FEMS Microbiology Letters, vol. 216, no. 2, pp. 249-253, 2002.

[24] C. S. Tsai and Q. Chen, "Purification and kinetic characterization of hexokinase and glucose-6-phosphate dehydrogenase from Schizosaccharomyces pombe," Biochemistry and Cell Biology, vol. 76, no. 1, pp. 107-113, 1998.

[25] G. B. Jagdale and R. Gordon, "Effect of temperature on the activities of glucose-6-phosphate dehydrogenase and hexokinase in entomopathogenic nematodes (Nematoda: Steinernematidae)," Comparative Biochemistry and Physiology A: Physiology, vol. 118, no. 4, pp. 1151-1156, 1997.

[26] P. Velasco, R. Barcia, I. Ibarguren, A. M. Sieiro, and J. I. RamosMartinez, "Purification, characterization and kinetic mechanism of glucose-6- phosphate dehydrogenase from mouse liver," International Journal of Biochemistry, vol. 26, no. 2, pp. 195-200, 1994.

[27] M. A. Askar, K. Sumathy, and N. Z. Baquer, "Regulation and properties of purified glucose-6-phosphate dehydrogenase from rat brain," Indian Journal of Biochemistry and Biophysics, vol. 33, no. 6, pp. 512-518, 1996.

[28] P. S. Tappia, C. J. P. Jones, and M. J. Connock, "Purification of guinea pig small intestinal peroxisomes and the subcellular localization of glucose-6-phosphate dehydrogenase," Molecular and Cellular Biochemistry, vol. 179, no. 1-2, pp. 13-20, 1998.

[29] M. Erat, "Purification of human erythrocyte glucose 6phosphate dehydrogenase and glutathione reductase enzymes using $2^{\prime}, 5^{\prime}$-ADP Sepharose 4B affinity column material in single chromatographic step," Protein Expression and Purification, vol. 34, no. 2, pp. 257-260, 2004.

[30] S. Adem and M. Ciftci, "Purification of rat kidney glucose 6-phosphate dehydrogenase, 6-phosphogluconate dehydrogenase, and glutathione reductase enzymes using $2^{\prime}, 5^{\prime}$-ADP Sepharose 4B affinity in a single chromatography step," Protein Expression and Purification, vol. 81, no. 1, pp. 1-4, 2012.

[31] K. Betke, G. J. Brewer, H. N. Kirkman et al., "Standardized method for G-6-PD assay of haemolysates," WHO Technical Report Series, vol. 366, pp. 30-32, 1967. 
[32] I. Smith, "Acrylamide gel disc electrophoresis," in Electrophoretic Techniques, I. Smith, Ed., pp. 365-515, Academic Press, New York, NY, USA, 1969.

[33] U. K. Laemmli, "Cleavage of structural proteins during the assembly of the head of bacteriophage T4," Nature, vol. 227, no. 5259, pp. 680-685, 1970.

[34] K. Weber and M. Osborn, "The reliability of molecular weight determinations by dodecyl sulfate-polyacrylamide gel electrophoresis," Journal of Biological Chemistry, vol. 244, no. 16, pp. 4406-4412, 1969.

[35] P. H. O'Farrell, "High resolution two dimensional electrophoresis of proteins," Journal of Biological Chemistry, vol. 250, no. 10, pp. 4007-4021, 1975.

[36] T. Ubuka, N. Masuoka, S. Yoshida, and K. Ishino, "Determination of isoelectric point value of 3-mercaptopyruvate sulfurtransferase by isoelectric focusing using ribonuclease Aglutathione mixed disulfides as standards," Analytical Biochemistry, vol. 167, no. 2, pp. 284-289, 1987.

[37] M. M. Bradford, "A rapid and sensitive method for the quantitation of microgram quantities of protein utilizing the principle of protein dye binding," Analytical Biochemistry, vol. 72, no. 1-2, pp. 248-254, 1976.

[38] C. O. Rangel-Yagui, H. Lam, D. T. Kamei, D. I. C. Wang, A. Pessoa Jr., and D. Blankschtein, "Glucose-6-phosphate dehydrogenase partitioning in two-phase aqueous mixed (nonionic/cationic) micellar systems," Biotechnology and Bioengineering, vol. 82, no. 4, pp. 445-456, 2003.

[39] N. N. Ulusu, B. Tandogan, and F. E. Tezcan, "Kinetic properties of glucose-6-phosphate dehydrogenase from lamb kidney cortex," Biochimie, vol. 87, no. 2, pp. 187-190, 2005.

[40] M. Cankaya, M. Sisecioglu, M. Ciftci, and H. Ozdemir, "Effects of some metal ions on trout liver glucose 6-phosphate Dehydrogenase," Research Journal of Environmental Toxicology, vol. 5, no. 6, pp. 385-391, 2011.

[41] F. Javier Corpas, L. García-Salguero, J. Peragón, and J. A. Lupiáñez, "Kinetic properties of hexose-monophosphate dehydrogenases. I. Isolation and partial purification of glucose-6phosphate dehydrogenase from rat liver and kidney cortex," Life Sciences, vol. 56, no. 3, pp. 179-189, 1994. 

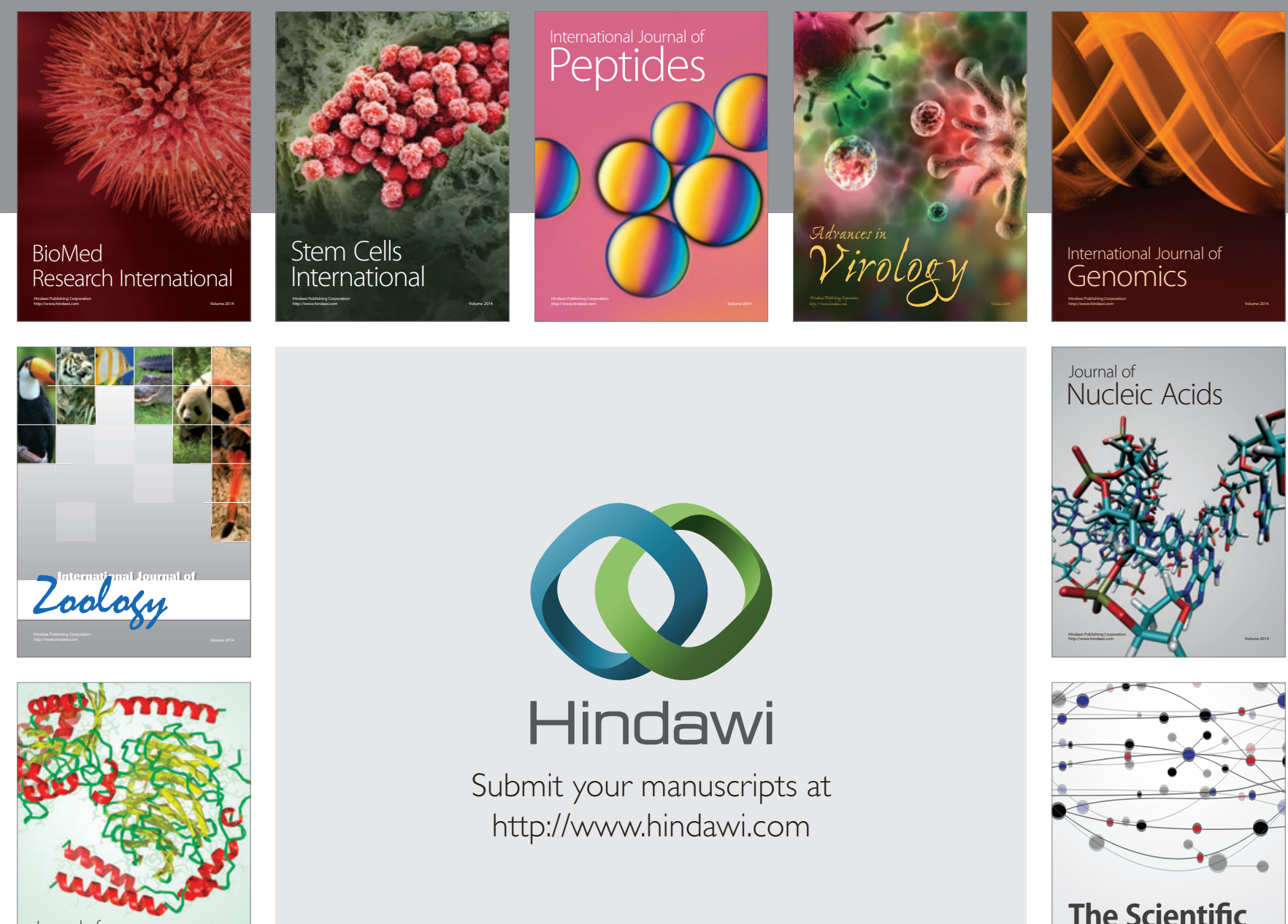

Submit your manuscripts at

http://www.hindawi.com

Journal of
Signal Transduction
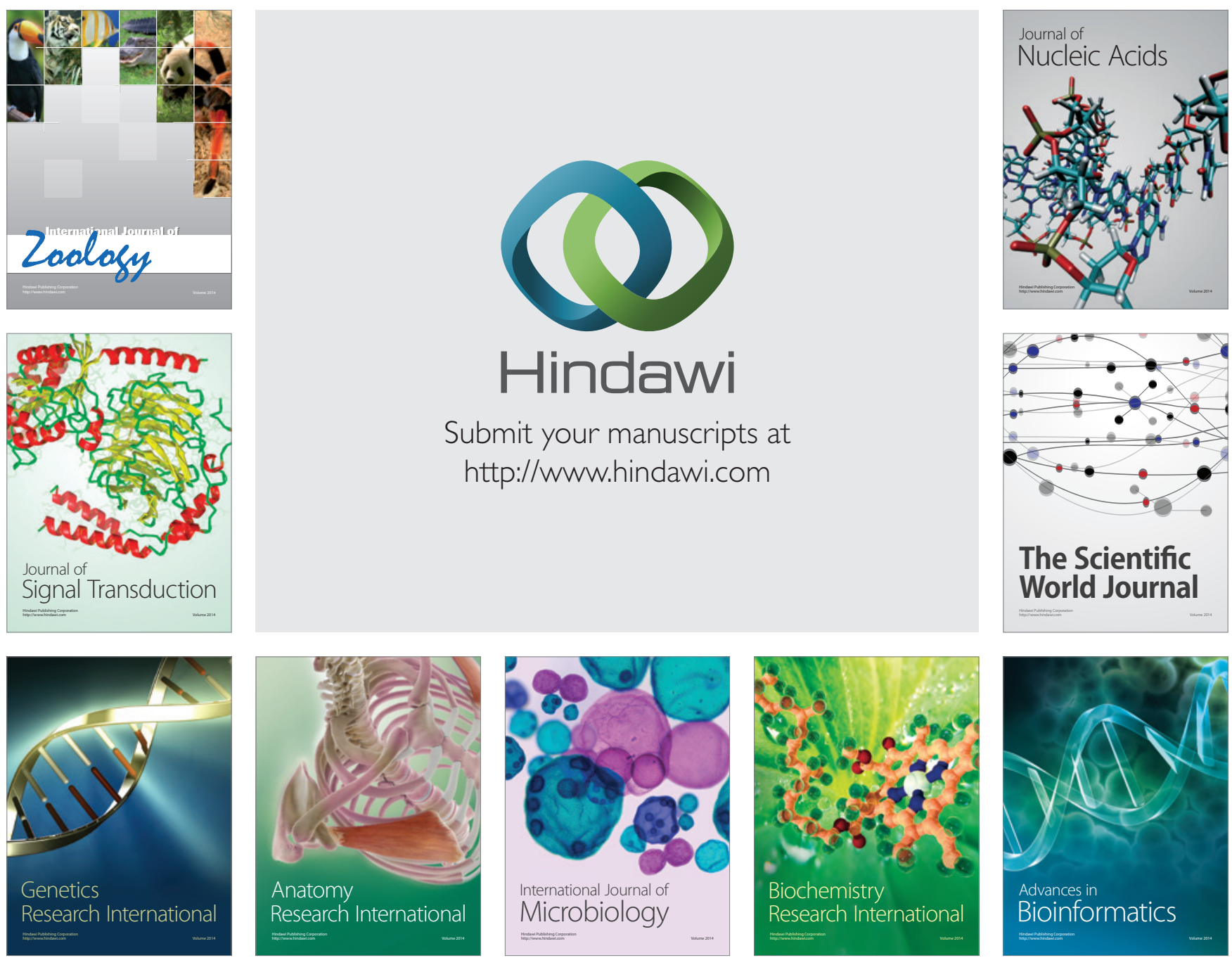

The Scientific World Journal
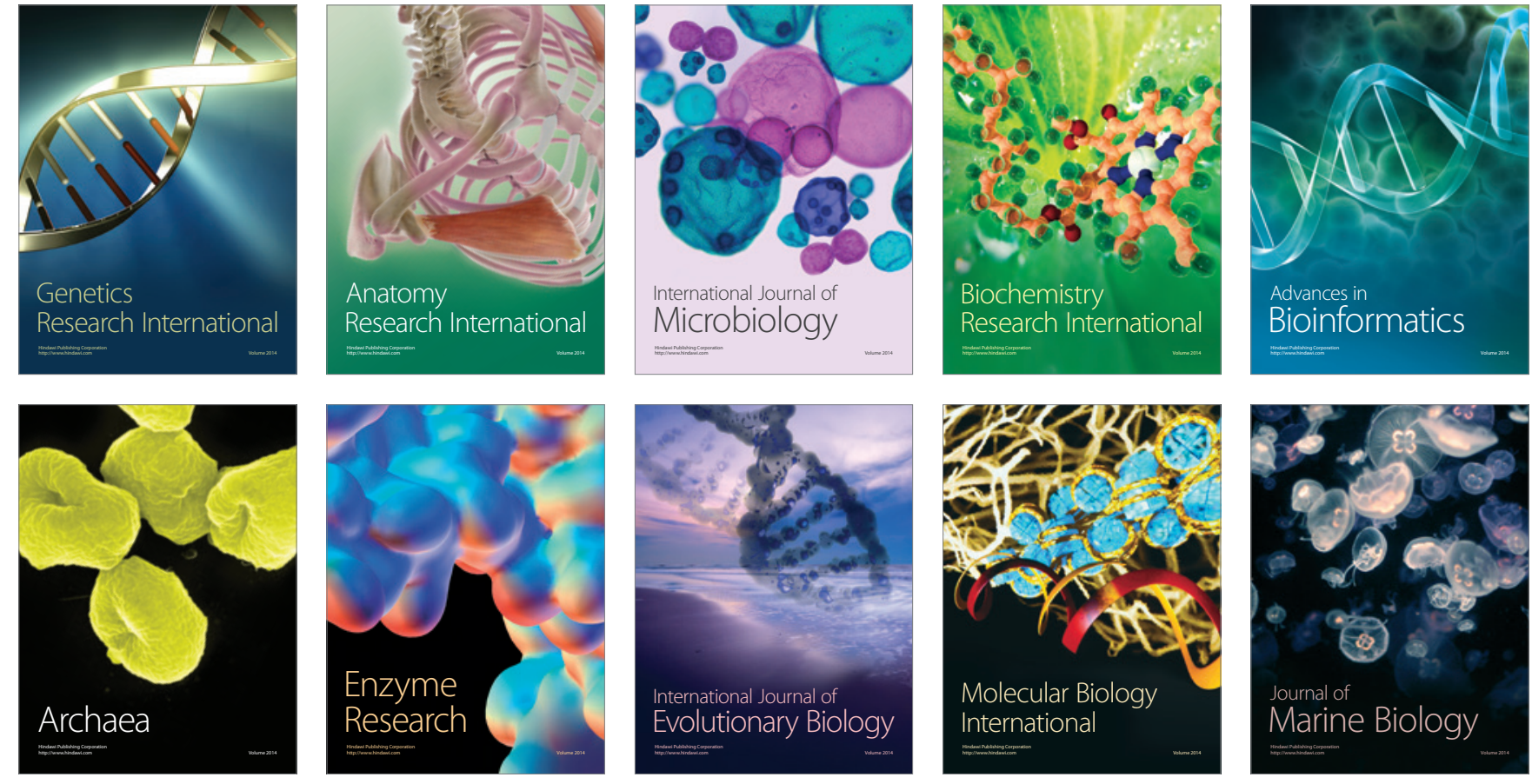